\title{
GSK-3 in Neurodegenerative Diseases
}

\author{
Peng Lei, ${ }^{1,2}$ Scott Ayton, ${ }^{1,3}$ Ashley I. Bush, ${ }^{1,2}$ and Paul A. Adlard ${ }^{1,2}$ \\ ${ }^{1}$ Mental Health Research Institute, 155 Oak Street, Parkville, VIC 3052, Australia \\ ${ }^{2}$ Department of Pathology, The University of Melbourne, Carlton, VIC 3010, Australia \\ ${ }^{3}$ Center for Neuroscience, The University of Melbourne, Carlton, VIC 3010, Australia \\ Correspondence should be addressed to Paul A. Adlard, p.adlard@mhri.edu.au
}

Received 27 January 2011; Accepted 7 March 2011

Academic Editor: Peter Crouch

Copyright () 2011 Peng Lei et al. This is an open access article distributed under the Creative Commons Attribution License, which permits unrestricted use, distribution, and reproduction in any medium, provided the original work is properly cited.

Glycogen synthase kinase-3 (GSK-3) regulates multiple cellular processes, and its dysregulation is implicated in the pathogenesis of diverse diseases. In this paper we will focus on the dysfunction of GSK-3 in Alzheimer's disease and Parkinson's disease. Specifically, GSK-3 is known to interact with tau, $\beta$-amyloid (A $\beta$ ), and $\alpha$-synuclein, and as such may be crucially involved in both diseases. A $\beta$ production, for example, is regulated by GSK-3, and its toxicity is mediated by GSK-induced tau phosphorylation and degeneration. $\alpha$-synuclein is a substrate for GSK-3 and GSK-3 inhibition protects against Parkinsonian toxins. Lithium, a GSK-3 inhibitor, has also been shown to affect tau, $\mathrm{A} \beta$, and $\alpha$-synuclein in cell culture, and transgenic animal models. Thus, understanding the role of GSK-3 in neurodegenerative diseases will enhance our understanding of the basic mechanisms underlying the pathogenesis of these disorders and also facilitate the identification of new therapeutic avenues.

\section{Introduction: GSK-3 Isoforms, Expression, and Neuronal Regulation}

Glycogen synthase kinase-3 (GSK-3) is a cellular serine/threonine protein kinase [1,2], belonging to the glycogen synthase kinase family [1]. It is involved in a number of cellular processes, including the division, proliferation, differentiation, and adhesion of cells [3]. Dysfunction of GSK-3 is implicated in diverse human diseases, including Alzheimer's disease (AD), Parkinson's Disease (PD), type 2 diabetes, bipolar disorder (BPD), and cancer $[3,4]$. Two isoforms of GSK-3 have been identified, namely, GSK- $3 \alpha$ and GSK- $3 \beta$, which although encoded by different genes are similarly regulated [5]. GSK-3 $\alpha(51 \mathrm{kDa})$ differs to GSK- $3 \beta$ $(47 \mathrm{kDa})$ in that the former has a glycine-rich extension at the amino-terminal end of the protein [5]. Both isoforms are ubiquitously expressed throughout the brain, with high levels of expression seen in the hippocampus, cerebral cortex, and the Purkinje cells of the cerebellum [6]. The expression ratio of these isoforms, however, favors GSK-3 $\beta[6,7]$.

The crystal structure of GSK-3 $\beta$ reveals a catalytically active dimer [8] conformation that progressively phosphorylates substrates with Ser/Thr pentad repeats [9].
Despite having disparate sequences, the isoforms have a conserved functional domain and share similar substrates, while remaining pharmacologically distinguishable [3]. The independent deletion of GSK-3 isoforms in mice resulted in a distinct profile of substrate phosphorylation [10], suggesting different functions of GSK-3 isoforms in the brain.

The activity of GSK-3 is dependent on phosphorylation at specific sites; phosphorylation of Ser9 of GSK-3 $\beta$, or Ser2 1 of GSK- $3 \alpha$, inhibits activity [9], whereas phosphorylation of Tyr216 on GSK-3 $\beta$ and Tyr279 on GSK-3 $\alpha$ increases activity [3]. It is thought that deactivation of GSK-3 has more influence on activity rather than activation, as the enzyme is constitutively active and the activation sites can undergo autophosphorylation [11].

The most well-studied GSK-3 regulation pathway is through Akt activation. Insulin stimulation, for example, can activate phosphatidylinositol 3-kinase (PI3K), which phosphorylates Akt (protein kinase B) and in turn inhibits GSK-3 [12-15]. A brief exposure to insulin, however, can also transiently activate GSK-3 $\beta$ by phosphorylating Tyr 216 through Fyn, a nonreceptor tyrosine kinase [13]. Other kinases, such as protein kinase C (PKC), inhibit GSK-3 activity by phosphorylating Ser9 $[14,16,17]$. The inhibition 
by PKC is additive to the inhibition by PI3K [14]. Additionally, within the brain, p38 mitogen-activated protein kinase (MAPK) inactivates GSK- $3 \beta$ by direct phosphorylation at its C-terminus [18].

Dephosphorylation of GSK-3 at inhibitory sites (thus activating the protein), is coordinated by protein phosphatase 1 (PP1), protein phosphatase 2A (PP2A), and protein phosphatase 2B (PP2B, calcineurin) [19-21]. PP1 preferentially acts as a phosphatase for GSK-3 $\beta$, while PP2A favors GSK-3 $\alpha$ [19]. On the other hand, the overexpression of GSK-3 $\beta$ inhibits PP2A, which may serve as a negative feedback mechanism for GSK-3 $\beta$ activity [22]. GSK-3 and its complex regulatory mechanisms have been extensively studied in a number of neurodegenerative diseases as outlined below.

\section{GSK-3 in AD and Tauopathies}

Alzheimer's disease is characterized by the accumulation of extracellular senile plaques and intracellular neurofibrillary tangles (NFTs) within the brain (for a review, see [23]). The major component of the plaques, which was first purified and identified from AD brains in the 1980s [24] and later shown to be a product of normal cellular metabolism [25], is $\beta$-amyloid $(\mathrm{A} \beta) . \mathrm{A} \beta$ is proteolytically processed from the amyloid precursor protein (APP) [26] via cleavage at the $\beta$-secretase site by BACE1 [27], followed by $\gamma$-secretase cleavage by presenilin (PS) [28]. The key component of the NFTs on the other hand, is the tau protein [29-31], which was originally identified as an intracellular microtubule stabilizer [32]. Both $\mathrm{A} \beta$ and tau are, therefore, fundamentally involved in driving the pathogenesis of $\mathrm{AD}$. With respect to this paper then, it is of note that both these proteins may be modulated by GSK-3. The most well-characterised interactions, however, occur with tau.

2.1. Tau. GSK-3 is one of the main kinases involved in the phosphorylation of tau, a process that is crucial to the function of the protein. The normal phosphorylation of tau determines its affinity for microtubule binding [29, 3335 ], with pathological hyperphosphorylation resulting in the dissociation of tau from microtubules and subsequent aggregation to form NFTs (for a review, see [36]). GSK-3 $\beta$ has been found to be associated with normal microtubule-bound tau [37] as well as with the hyperphosphorylated tau deposits in the AD brain $[38,39]$. There are several lines of evidence that support a direct functional link between tau phosphorylation and GSK-3. For example, in vitro and in cell culture models, both GSK- $3 \alpha$ and GSK-3 $\beta$ can phosphorylate tau at various sites that are consistent with the epitopes found to be hyperphosphorylated in $\mathrm{AD}$ brains [40-45]. The overexpression of GSK-3 $\beta$ in animal models also promotes the phosphorylation of tau, implicating it as an in vivo tau kinase [46-49]. Conversely, the inhibition of GSK-3 $\beta$ activity by either GSK-3 inhibitors or upstream Akt inhibitors reduces tau phosphorylation [50-58]. GSK-3 $\beta$ thus affects tau function through interfering with tau phosphorylation, thereby disrupting microtubule stability $[59,60]$, self-assembly of microtubules $[61,62]$, the microtubule-dependent cell processes [63], and regulation of organelle transport and axonal transportation [64-66]. Interestingly, the overexpression of tau also increased GSK-3 $\beta$ activity, which perpetuated the phosphorylation of tau [67].

In addition to effects on phosphorylation, the activation of GSK-3 $\beta$ may also facilitate the aggregation of tau [68-71]. Furthermore, the in vivo overexpression of GSK-3 $\beta$ accelerates tau-induced neurodegeneration $[47,49,71,72]$, while the inhibition of its activity reduces tau toxicity [7375]. Conversely, in the absence of tau, the neurodegenerative and cognitive phenotype observed in GSK3-overexpresing mice is ameliorated, suggesting that tau may mediate GSK$3 \beta$ toxicity [76]. In addition, GSK-3 may regulate tau-mRNA splicing [77] and expression [78] by disrupting transcription [79].

2.2. $\beta$-Amyloid. Accumulating evidence suggests that GSK3 interferes with the biology of $\mathrm{A} \beta$, which is believed to be upstream of tau in the pathogenesis of $\mathrm{AD}$ [23]. $\mathrm{A} \beta$ accelerates tau pathology $[80,81]$ and promotes tau phosphorylation by several mechanisms, including activation of GSK-3 $\beta$ [82-84]. The use of A $\beta$ antibodies both in vitro and in vivo decreases GSK-3 activity, supporting the interaction between $A \beta$ and GSK-3 [85]. It has also been shown that the activation of GSK by $\mathrm{A} \beta$ in primary hippocampal cultures is specific to GSK-3 $\beta$ [86], and that the inhibition of GSK-3 $\beta$ prevents $\mathrm{A} \beta$-induced toxicity to neurons [82, $84,87,88$ ]. Likewise, although both isoforms of GSK-3 are hyperactivated in transgenic mice expressing mutant APP (V717I) [89], the data from this model together with that from a model expressing the intracellular domain of APP [90] firmly support the notion that it is the activation of GSK $-3 \beta$ by amyloid that results in downstream pathological effects on tau. The A $\beta$-induced activation of GSK- 3 also only needs to be transient to result in tau hyperphosphorylation and other effects such as mitochondrial trafficking impairments [91]. Finally, tau null mice are protected against A $\beta$ induced toxicity [92, 93] and GSK-induced toxicity [76], which taken together with the discussed data highlight the complex interaction between GSK, $\mathrm{A} \beta$, and tau. This is further complicated by the fact that GSK-3 is involved in APP processing and subsequent $\mathrm{A} \beta$ production.

The amyloid precursor protein and PS1 are substrates of GSK-3 [94-98], and GSK-3 $\alpha$ is thought to regulate $\mathrm{A} \beta$ production by interfering with APP cleavage at the $\gamma$-secretase step [99]. Co-overexpression of GSK-3 $\alpha$ and APP in CHO cells increased the level of $\mathrm{A} \beta$ in a dose-dependent manner, while selective reduction of GSK- $3 \alpha$ protein expression by RNAi decreased A $\beta$ levels [99]. Although Phiel et al. [99] showed an opposite role of GSK-3 $\beta$ in their study, GSK$3 \beta$ was later shown to decrease $\mathrm{A} \beta$ levels by an unknown pathway [100]. Nevertheless, the genetic or pharmacological deactivation of GSK-3 reduces $\mathrm{A} \beta$ and its associated toxicity, ameliorates $\mathrm{A} \beta$-induced behavioral deficits, and rescues neuronal loss in APP-overexpressing mouse models [101103], thus strongly implicating GSK-3 in the pathogenesis of AD. 


\section{GSK-3 in Parkinson's Disease}

Parkinson's disease is characterized by dopaminergic neuron degeneration in the substantia nigra pars compacta ( $\mathrm{SNpc}$ ) with Lewy body (LB) pathology, accompanied by clinically defined parkinsonism [104]. As there is a potential role of tau emerging in PD [105-107], then the function of GSK-3 in PD has also thus been investigated. The examination of postmortem tissue from PD patients has revealed that GSK$3 \beta$, phosphorylated at Ser 9 , is specifically localised within the halo of LBs [108] and that GSK-3 $\beta$ activity is also elevated in the striatum [109]. This latter finding has been recapitulated in mouse models of PD [110]. Increased GSK-3 levels have also been reported in peripheral blood lymphocytes in PD patients [111], and polymorphisms in GSK-3 $\beta$, which affect its transcription and splicing, are also associated with disease risk in PD when stratifying by tau haplotype $[112,113]$.

Mechanistically there is evidence to support an interaction between $\alpha$-synuclein, a $16 \mathrm{kDa}$ natively unstructured protein that is fundamentally involved in the pathogenesis of PD, and GSK. Aggregated $\alpha$-synuclein species are the main component of LBs and single nucleotide polymorphisms and duplication or triplication of the $\alpha$-synuclein gene cause familial Parkinsonian degeneration [104]. $\alpha$-synuclein, which is a substrate for GSK-3 $\beta$ phosphorylation, may also modulate the activation of GSK-3 $\beta$ [114]; GSK-3 $\beta$ phosphorylation at Tyr216 (which activates GSK-3 activity) is also abolished in cells lacking $\alpha$-synuclein and in $\alpha$ synuclein knockout mice [110]. The potential role of GSK$3 \beta$ in PD has been elucidated in the 1-methyl-4-phenyl1,2,3,6-tetrahydropyridine (MPTP) model of PD, where the inhibition of GSK- $3 \beta$ protects against MPTP toxicity in vitro and in vivo $[56,110,115]$ and decreases $\alpha$-synuclein protein expression [56]. Taken together, these data strongly implicate GSK-3 in the pathogenesis of PD. The neuroprotective possibilities of GSK-3 inhibition on A $\beta$, tau and $\alpha$-synuclein pathology have thus been explored in depth, most extensively with lithium.

\section{Lithium: A GSK-3 Inhibitor}

Lithium, a monovalent cation, affects multiple cellular processes in model organisms and humans (for a review, see [116]). Importantly, it has been used as a mood stabilizer and primary therapy for BPD since its discovery by Cade in 1949 [117]. Although effective in many cases, lithium exhibits a narrow therapeutic window, and side effects may occur within the therapeutic dose range [118]. Lithium is suggested to have several molecular targets in BPD, one leading mechanism of action is the inhibition of GSK-3 [116].

Haplo-insufficiency of GSK- $3 \beta$ mimics behavioral and molecular effects of lithium [119], while GSK-3 $\beta$ overexpression mimics mania and hyperactivity in a mouse model [120], supporting GSK-3 $\beta$ as a relevant target of lithium action [121]. With an inhibitory Ki of $2 \mathrm{mM}$ [121], lithium inhibits both GSK-3 $\alpha$ and GSK-3 $\beta$ directly through competitive inhibition of $\mathrm{Mg}^{2+}$ [122], and indirectly through the modulation of post-translational modifications of GSK-3
$[123,124]$ in a number of species [125]. Lithium is selective for GSK-3 $\alpha$ and GSK-3 $\beta$ and does not inhibit other protein kinases tested in vitro and in vivo, including casein kinase II, protein kinase A and C, MAPK, and CDK5 [121, 126]. When utilized at therapeutic concentrations in various cell culture models, lithium reduces tau phosphorylation [53, 127-129] and the processing of APP to generate A $\beta[99,130,131]$, suggesting that lithium may have important implications in both $\mathrm{AD}$ and BPD. However, some of these findings have been disputed, with lithium shown to increase $\beta$-secretase activity and to subsequently elevate extracellular $A \beta$ levels in $\mathrm{CHO}$ cells and rat cortical neurons [132]. In this case, the activity of $\gamma$-secretase was unaltered, suggesting that the lithium-induced elevation of $A \beta$ was independent of GSK3 inhibition [132]. In addition, lithium treatment has been shown to reduce tau protein and mRNA levels in cultured cortical neurons [79].

Nevertheless, lithium has been assessed for its potential efficacy in treating "AD-like" pathology in vivo. In wild-type rats, lithium has been shown to reduce tau phosphorylation and inhibit GSK-3 activity [133] and to also enhance spatial memory $[134,135]$. Using transgenic animals characterised by progressive $A \beta$ deposition, lithium treatment has been consistently found to decrease A $\beta$ levels and APP phosphorylation, as well as to reduce GSK-3 activity and tau phosphorylation $[99,101,136-138]$. In contrast to previous cell culture studies, however, $\beta$-secretase activity has been unaffected $[101,132]$. Lithium treatment has also been shown to prevent $A \beta$ toxicity [136], preserve dendritic structure [101], facilitate neurogenesis [138], and rescue $A \beta$ induced cognitive impairment $[101,137,138]$.

Less clear, however, is the efficacy of lithium against tau-mediated degeneration. Mice that overexpress diseaselinked tau exhibit reduced tau phosphorylation with lithium treatment [55, 73-75, 139]. In addition, tau transgenic models have attenuated axonal degeneration with lithium treatment [55], but no motor or working memory recovery [139]. Lithium-treated 3XTg mice (harbouring both tau and $\mathrm{A} \beta$ pathology) have reduced GSK-3 activity and tau phosphorylation, but no change in $A \beta$ levels or working memory [126]. However, in accordance with cell culture studies [53, 127-129] GSK-3 activity remained the same in a long-term (5 months) lithium trial [74], possibly suggesting that the protection offered by lithium is GSK-3 independent. The authors [74] alternatively suggested that lithium reduced the tau lesion primarily by promoting its ubiquitination and degradation rather than by inhibiting its phosphorylation through GSK-3.

While these in vitro and in vivo studies reveal a beneficial effect of lithium on tau and $\mathrm{A} \beta$ pathology, a number of observational studies and case reports have provided conflicting evidence, with both positive [140-144] and negative outcomes $[145,146]$ on dementia reported. Despite this, lithium has recently been evaluated as a therapy for $\mathrm{AD}$ in a 10-week multicenter, randomized, single-blind, and placebo-controlled trial [147]. GSK-3 activity was monitored in lymphocytes at 1-2 week intervals, total and phosphorylated tau levels were assessed in the CSF, and $\mathrm{A} \beta_{(1-42)}$ levels were assessed in the CSF and plasma at the end of 
treatment. Cognitive function was assessed using the MiniMental State Examination (MMSE), the Alzheimer's disease Assessment Scale-Cognitive subscale (ADAS-Cog) and the Neuropsychiatric Inventory (NPI). The study concluded that lithium was not an effective therapeutic for $\mathrm{AD}$, as there were no significant effects on any of the endpoint measurements. A post-hoc examination on a subset of individuals did, however, reveal an increase in serum BDNF that was inversely correlated with decreased ADAS-Cog sum scores [148]. Further long-term studies are required to determine the safety and efficiency of lithium or other GSK-3 inhibitors for the treatment of AD.

In pursuit of GSK-3 regulation in $\mathrm{PD}$, lithium has also been tested in animal models of this disease. The data, however, are not conclusive, with lithium shown to both protect against the dopamine depletion resulting from MPTP toxicity [149] and to also cause a decrease in brain dopamine (DA) release [150] that leads to deficits in DA levels [151]. Furthermore, lithium treatment does not prevent dopaminergic neuron loss in the related 6-OHDA model of PD [152]. There is, therefore, currently little evidence to support lithium as a treatment strategy for PD. The data on the use of lithium in other human neurodegenerative diseases is also not compelling.

Lithium, for example, has also been investigated as a therapy for one of the motor-neuron diseases, amyotrophic lateral sclerosis (ALS), despite the lack of an established connection with GSK-3. Although lithium was found to delay disease onset and to reduce neurological deficits in both ALS mouse models and a small human trial $[153,154]$, other mouse and human trials have shown detrimental effects $[155,156]$. The potential utility of lithium in ALS, or indeed in any of the neurodegenerative disorders outlined above, remains unclear. It is likely that lithium has other activities, independent of GSK-3, that may mediate its pharmacodynamics.

\section{Concluding Remarks}

We have summarized the latest knowledge regarding GSK3 and its involvement in neurodegenerative diseases such as $\mathrm{AD}$ and $\mathrm{PD}$. Although extensive research has been undertaken in the last decade, the role of GSK-3 in disease pathogenesis has yet to be fully elucidated. The inhibition of GSK-3 may be a potential target for $\mathrm{AD}$, since it has regulatory effects on both $\mathrm{A} \beta$ and tau. Similarly, GSK3 inhibition could interact with $\alpha$-synuclein to affect the pathogenesis of PD. The intriguing preclinical data, however, has yet to be translated into an effective pharmacotherapy for neurodegeneration, perhaps in part owing to the complex regulation of GSK and its activity on multiple substrates. Future endeavors should investigate alternative modulators of GSK-3 and annotate more precise mechanisms of how the isoforms of GSK-3 participate in neurodegeneration.

\section{Acknowledgments}

This paper funded by the National Health and Medical Research Council of Australia and the Australian Research
Council. The authors thank Y. H. Hung for helpful discussions and proofreading.

\section{References}

[1] N. Embi, D. B. Rylatt, and P. Cohen, "Glycogen synthase kinase-3 from rabbit skeletal muscle. Separation from cyclicAMP-dependent protein kinase and phosphorylase kinase," European Journal of Biochemistry, vol. 107, no. 2, pp. 519527, 1980.

[2] D. B. Rylatt, A. Aitken, T. Bilham, G. D. Condon, N. Embi, and P. Cohen, "Glycogen synthase from rabbit skeletal muscle. Amino acid sequence at the sites phosphorylated by glycogen synthase kinase-3, and extension of the Nterminal sequence containing the site phosphorylated by phosphorylase kinase," European Journal of Biochemistry, vol. 107, no. 2, pp. 529-537, 1980.

[3] L. Kockeritz, B. Doble, S. Patel, and J. R. Woodgett, "Glycogen synthase kinase-3 - an overview of an over-achieving protein kinase," Current Drug Targets, vol. 7, no. 11, pp. 1377-1388, 2006.

[4] S. Frame and P. Cohen, "GSK3 takes centre stage more than 20 years after its discovery," Biochemical Journal, vol. 359, no. 1, pp. 1-16, 2001.

[5] J. R. Woodgett, "Molecular cloning and expression of glycogen synthase kinase-3/factor A," The EMBO Journal, vol. 9, no. 8, pp. 2431-2438, 1990.

[6] H. B. Yao, P. C. Shaw, C. C. Wong, and D. C. C. Wan, "Expression of glycogen synthase kinase-3 isoforms in mouse tissues and their transcription in the brain," Journal of Chemical Neuroanatomy, vol. 23, no. 4, pp. 291-297, 2002.

[7] K. F. Lau, C. C. J. Miller, B. H. Anderton, and P. C. Shaw, "Expression analysis of glycogen synthase kinase-3 in human tissues," Journal of Peptide Research, vol. 54, no. 1, pp. 85-91, 1999.

[8] M. Aoki, M. Iwamoto-Sugai, I. Sugiura et al., "Expression, purification and crystallization of human tau-protein kinase I/glycogen synthase kinase-3 $\beta$," Acta Crystallographica Section D, vol. 56, no. 11, pp. 1464-1465, 2000.

[9] R. Dajani, E. Fraser, S. M. Roe et al., "Crystal structure of glycogen synthase kinase $3 \beta$ : structural basis for phosphateprimed substrate specificity and autoinhibition," Cell, vol. 105, no. 6, pp. 721-732, 2001.

[10] M. P. M. Soutar, W.-Y. Kim, R. Williamson et al., "Evidence that glycogen synthase kinase-3 isoforms have distinct substrate preference in the brain," Journal of Neurochemistry, vol. 115, no. 4, pp. 974-983, 2010.

[11] A. Cole, S. Frame, and P. Cohen, "Further evidence that the tyrosine phosphorylation of glycogen synthase kinase3 (GSK3) in mammalian cells is an autophosphorylation event," Biochemical Journal, vol. 377, no. 1, pp. 249-255, 2004.

[12] D. A. E. Cross, D. R. Alessi, P. Cohen, M. Andjelkovich, and B. A. Hemmings, "Inhibition of glycogen synthase kinase-3 by insulin mediated by protein kinase B," Nature, vol. 378, no. 6559, pp. 785-789, 1995.

[13] M. Lesort, R. S. Jope, and G. V. W. Johnson, "Insulin transiently increases tau phosphorylation: involvement of glycogen synthase kinase- $3 \beta$ and Fyn tyrosine kinase," Journal of Neurochemistry, vol. 72, no. 2, pp. 576-584, 1999.

[14] S. J. Liu, AI. H. Zhang, H. L. Li et al., "Overactivation of glycogen synthase kinase- 3 by inhibition of phosphoinositol3 kinase and protein kinase $\mathrm{C}$ leads to hyperphosphorylation 
of tau and impairment of spatial memory," Journal of Neurochemistry, vol. 87, no. 6, pp. 1333-1344, 2003.

[15] V. Meske, F. Albert, and T. G. Ohm, "Coupling of mammalian target of rapamycin with phosphoinositide 3-kinase signaling pathway regulates protein phosphatase $2 \mathrm{a}$ - and glycogen synthase kinase- $3 \beta$-dependent phosphorylation of tau," Journal of Biological Chemistry, vol. 283, no. 1, pp. 100-109, 2008.

[16] T. Isagawa, H. Mukai, K. Oishi et al., "Dual effects of $\mathrm{PKN} \alpha$ and protein kinase $\mathrm{C}$ on phosphorylation of tau protein by glycogen synthase kinase-3 $\beta$," Biochemical and Biophysical Research Communications, vol. 273, no. 1, pp. 209-212, 2000.

[17] I. Tsujio, T. Tanaka, T. Kudo et al., "Inactivation of glycogen synthase kinase- 3 by protein kinase $\mathrm{C} \delta$ : implications for regulation of $\tau$ phosphorylation," FEBS Letters, vol. 469, no. 1, pp. 111-117, 2000.

[18] T. M. Thornton, G. Pedraza-Alva, B. Deng et al., "Phosphorylation by $\mathrm{p} 38 \mathrm{MAPK}$ as an alternative pathway for GSK-3 $\beta$ inactivation," Science, vol. 320, no. 5876, pp. 667-670, 2008.

[19] F. Hernández, E. Langa, R. Cuadros, J. Avila, and N. Villanueva, "Regulation of GSK3 isoforms by phosphatases PP1 and PP2A," Molecular and Cellular Biochemistry, vol. 344, no. 1-2, pp. 211-215, 2010.

[20] S. Peineau, C. Taghibiglou, C. Bradley et al., "LTP inhibits LTD in the hippocampus via regulation of GSK-3 $\beta$," Neuron, vol. 53, no. 5, pp. 703-717, 2007.

[21] Y. Kim, Y. I. Lee, M. Seo et al., "Calcineurin dephosphorylates glycogen synthase kinase-3 beta at serine- 9 in neuroblastderived cells," Journal of Neurochemistry, vol. 111, no. 2, pp. 344-354, 2009.

[22] G. P. Liu, Y. Zhang, X. Q. Yao et al., "Activation of glycogen synthase kinase-3 inhibits protein phosphatase-2A and the underlying mechanisms," Neurobiology of Aging, vol. 29, no. 9, pp. 1348-1358, 2008.

[23] K. Blennow, M. J. de Leon, and H. Zetterberg, “Alzheimer's disease," The Lancet, vol. 368, no. 9533, pp. 387-403, 2006.

[24] C. L. Masters, G. Simms, and N. A. Weinman, "Amyloid plaque core protein in Alzheimer disease and Down syndrome," Proceedings of the National Academy of Sciences of the United States of America, vol. 82, no. 12, pp. 4245-4249, 1985.

[25] C. Haass, M. G. Schlossmacher, A. Y. Hung et al., "Amyloid $\beta$-peptide is produced by cultured cells during normal metabolism," Nature, vol. 359, no. 6393, pp. 322-325, 1992.

[26] R. E. Tanzi, "The Alzheimer disease-associated amyloid beta protein precursor gene and familial Alzheimer disease," Progress in Clinical and Biological Research, vol. 360, pp. 187199, 1990.

[27] R. Vassar, B. D. Bennett, S. Babu-Khan et al., " $\beta$-Secretase cleavage of Alzheimer's amyloid precursor protein by the transmembrane aspartic protease BACE," Science, vol. 286, no. 5440, pp. 735-741, 1999.

[28] M. S. Wolfe, W. Xia, B. L. Ostaszewski, T. S. Diehl, W. T. Kimberly, and D. J. Selkoe, "Two transmembrane aspartates in presenilin-1 required for presenilin endoproteolysis and $\gamma$ secretase activity," Nature, vol. 398, no. 6727, pp. 513-517, 1999.

[29] I. Grundke-Iqbal, K. Iqbal, and Y. C. Tung, "Abnormal phosphorylation of the microtubule-associated protein $\tau$ (tau) in Alzheimer cytoskeletal pathology," Proceedings of the National Academy of Sciences of the United States of America, vol. 83, no. 13, pp. 44913-4917, 1986.

[30] I. Grundke-Iqbal, K. Iqbal, and M. Quinlan, "Microtubuleassociated protein tau. A component of Alzheimer paired helical filaments," Journal of Biological Chemistry, vol. 261, no. 13, pp. 6084-6089, 1986.

[31] K. S. Kosik, C. L. Joachim, and D. J. Selkoe, "Microtubuleassociated protein tau $(\tau)$ is a major antigenic component of paired helical filaments in Alzheimer disease," Proceedings of the National Academy of Sciences of the United States of America, vol. 83, no. 11, pp. 4044-4048, 1986.

[32] M. D. Weingarten, A. H. Lockwood, S. Y. Hwo, and M. W. Kirschner, "A protein factor essential for microtubule assembly," Proceedings of the National Academy of Sciences of the United States of America, vol. 72, no. 5, pp. 1858-1862, 1975.

[33] P. Seubert, M. Mawal-Dewan, R. Barbour et al., "Detection of phosphorylated Ser in fetal tau, adult tau, and paired helical filament tau," Journal of Biological Chemistry, vol. 270, no. 32, pp. 18917-18922, 1995.

[34] A. Harada, K. Oguchi, S. Okabe et al., "Altered microtubule organization in small-calibre axons of mice lacking tau protein," Nature, vol. 369, no. 6480, pp. 488-491, 1994.

[35] G. T. Bramblett, M. Goedert, R. Jakes, S. E. Merrick, J. Q. Trojanowski, and V. M. Y. Lee -, "Abnormal tau phosphorylation at $\mathrm{Ser}^{396}$ in Alzheimer's disease recapitulates development and contributes to reduced microtubule binding," Neuron, vol. 10, no. 6, pp. 1089-1099, 1993.

[36] V. M. Y. Lee, M. Goedert, and J. Q. Trojanowski, "Neurodegenerative tauopathies," Annual Review of Neuroscience, vol. 24, pp. 1121-1159, 2001.

[37] W. Sun, H. Y. Qureshi, P. W. Cafferty et al., "Glycogen synthase kinase- $3 \beta$ is complexed with tau protein in brain microtubules," Journal of Biological Chemistry, vol. 277, no. 14, pp. 11933-11940, 2002.

[38] I. Ferrer, M. Barrachina, and B. Puig, "Glycogen synthase kinase-3 is associated with neuronal and glial hyperphosphorylated tau deposits in Alzheimer's diasese, Pick's disease, progressive supranuclear palsy and corticobasal degeneration," Acta Neuropathologica, vol. 104, no. 6, pp. 583-591, 2002.

[39] H. Yamaguchi, K. Ishiguro, T. Uchida, A. Takashima, C. A. Lemere, and K. Imahori, "Preferential labeling of Alzheimer neurofibrillary tangles with antisera for tau protein kinase (TPK) I/glycogen synthase kinase-3 $\beta$ and cyclin-dependent kinase 5, a component of TPK II," Acta Neuropathologica, vol. 92, no. 3, pp. 232-241, 1996.

[40] D. P. Hanger, K. Hughes, J. R. Woodgett, J. P. Brion, and B. H. Anderton, "Glycogen synthase kinase-3 induces Alzheimer's disease-like phosphorylation of tau: generation of paired helical filament epitopes and neuronal localisation of the kinase," Neuroscience Letters, vol. 147, no. 1, pp. 58-62, 1992.

[41] E. M. Mandelkow, G. Drewes, J. Biernat et al., "Glycogen synthase kinase- 3 and the Alzheimer-like state of microtubuleassociated protein tau," FEBS Letters, vol. 314, no. 3, pp. 315321, 1992.

[42] S. Lovestone, C. H. Reynolds, D. Latimer et al., "Alzheimer's disease-like phosphorylation of the microtubule-associated protein tau by glycogen synthase kinase-3 in transfected mammalian cells," Current Biology, vol. 4, no. 12, pp. 10771086, 1994.

[43] F. J. Moreno, M. Medina, M. Perez, E. Montejo De Garcini, and J. Avila, "Glycogen synthase kinase 3 phosphorylates recombinant human tau protein at serine-262 in the presence of heparin (or tubulin)," FEBS Letters, vol. 372, no. 1, pp. 6568, 1995. 
[44] B. R. Sperbera, S. Leight, M. Goedert, and V. M. Lee, "Glycogen synthase kinase- $3 \beta$ phosphorylates tau protein at multiple sites in intact cells," Neuroscience Letters, vol. 197, no. 2, pp. 149-153, 1995.

[45] T. Li and H. K. Paudel, "Glycogen synthase kinase $3 \beta$ phosphorylates Alzheimer's disease-specific $\operatorname{Ser}^{396}$ of microtubule-associated protein tau by a sequential mechanism," Biochemistry, vol. 45, no. 10, pp. 3125-3133, 2006.

[46] J. Brownlees, N. G. Irving, J. P. Brion et al., "Tau phosphorylation in transgenic mice expressing glycogen synthase kinase-3 $\beta$ transgenes," NeuroReport, vol. 8, no. 15, pp. 32513255, 1997.

[47] J. J. Lucas, F. Hernández, P. Gómez-Ramos, M. A. Morán, R. Hen, and J. Avila, "Decreased nuclear $\beta$-catenin, tau hyperphosphorylation and neurodegeneration in GSK-3 $\beta$ conditional transgenic mice," The EMBO Journal, vol. 20, no. 1-2, pp. 27-39, 2001.

[48] T. Engel, P. Goñi-Oliver, P. Gomez-Ramos et al., "Hippocampal neuronal subpopulations are differentially affected in double transgenic mice overexpressing frontotemporal dementia and parkinsonism linked to chromosome 17 tau and glycogen synthase kinase-3 $\beta$," Neuroscience, vol. 157, no. 4, pp. 772-780, 2008.

[49] K. Spittaels, C. van den Haute, J. van Dorpe et al., "Glycogen synthase kinase- $3 \beta$ phosphorylates protein tau and rescues the axonopathy in the central nervous system of human fourrepeat tau transgenic mice," Journal of Biological Chemistry, vol. 275, no. 52, pp. 41340-41349, 2000.

[50] T. M. Malm, H. Iivonen, G. Goldsteins et al., "Pyrrolidine dithiocarbamate activates Akt and improves spatial learning in APP/PS1 mice without affecting $\beta$-amyloid burden," Journal of Neuroscience, vol. 27, no. 14, pp. 3712-3721, 2007.

[51] H. R. Shi, L. Q. Zhu, S. H. Wang et al., "17 $\beta$-estradiol attenuates glycogen synthase kinase- $3 \beta$ activation and tau hyperphosphorylation in Akt-independent manner," Journal of Neural Transmission, vol. 115, no. 6, pp. 879-888, 2008.

[52] Z. Zhang, R. Zhao, J. Qi, S. Wen, Y. Tang, and D. Wang, "Inhibition of glycogen synthase kinase- $3 \beta$ by Angelica sinensis extract decreases $\beta$-amyloid-induced neurotoxicity and tau phosphorylation in cultured cortical neurons," Journal of Neuroscience Research, vol. 89, no. 3, pp. 437-447, 2011.

[53] M. Takahashi, K. Yasutake, and K. Tomizawa, "Lithium inhibits neurite growth and tau protein kinase I/glycogen synthase kinase- $3 \beta$-dependent phosphorylation of juvenile tau in cultured hippocampal neurons," Journal of Neurochemistry, vol. 73, no. 5, pp. 2073-2083, 1999.

[54] S. Leclerc, M. Garnier, R. Hoessel et al., "Indirubins inhibit glycogen synthase kinase- $3 \beta$ and CDK5/P25, two protein kinases involved in abnormal tau phosphorylation in Alzheimer's disease. A property common to most cyclindependent kinase inhibitors?" Journal of Biological Chemistry, vol. 276, no. 1, pp. 251-260, 2001.

[55] W. Noble, E. Planel, C. Zehr et al., "Inhibition of glycogen synthase kinase-3 by lithium correlates with reduced tauopathy and degeneration in vivo," Proceedings of the National Academy of Sciences of the United States of America, vol. 102, no. 19, pp. 6990-6995, 2005.

[56] A. P. Kozikowski, I. N. Gaisina, P. A. Petukhov et al., "Highly potent and specific GSK- $3 \beta$ inhibitors that block tau phosphorylation and decrease $\alpha$-synuclein protein expression in a cellular model of Parkinson's disease," ChemMedChem, vol. 1, no. 2, pp. 256-266, 2006.
[57] S. J. Greco, S. Sarkar, G. Casadesus et al., "Leptin inhibits glycogen synthase kinase- $3 \beta$ to prevent tau phosphorylation in neuronal cells," Neuroscience Letters, vol. 455, no. 3, pp. 191-194, 2009.

[58] P. J. Crouch, W. H. Lin, P. A. Adlard et al., "Increasing Cu bioavailability inhibits $A \beta$ oligomers and tau phosphorylation," Proceedings of the National Academy of Sciences of the United States of America, vol. 106, no. 2, pp. 381-386, 2009.

[59] S. Lovestone, C. L. Hartley, J. Pearce, and B. H. Anderton, "Phosphorylation of tau by glycogen synthase kinase- $3 \beta$ in intact mammalian cells: the effects on the organization and stability of microtubules," Neuroscience, vol. 73, no. 4, pp. 1145-1157, 1996.

[60] H. Sang, Z. Lu, Y. Li, B. Ru, W. Wang, and J. Chen, "Phosphorylation of tau by glycogen synthase kinase $3 \beta$ in intact mammalian cells influences the stability of microtubules," Neuroscience Letters, vol. 312, no. 3, pp. 141-144, 2001.

[61] M. A. Utton, A. Vandecandelaere, U. Wagner et al., "Phosphorylation of tau by glycogen synthase kinase $3 \beta$ affects the ability of tau to promote microtubule self-assembly," Biochemical Journal, vol. 323, no. 3, pp. 741-747, 1997.

[62] J. H. Cho and G. V. W. Johnson, "Glycogen synthase kinase $3 \beta$ phosphorylates tau at both primed and unprimed sites: differential impact on microtubule binding," Journal of Biological Chemistry, vol. 278, no. 1, pp. 187-193, 2003.

[63] K. Leroy, R. Menu, J. L. Conreur et al., "The function of the microtubule-associated protein tau is variably modulated by graded changes in glycogen synthase kinase- $3 \beta$ activity," FEBS Letters, vol. 465, no. 1, pp. 34-38, 2000.

[64] Y. Tatebayashi, N. Haque, Y. C. Tung, K. Iqbal, and I. Grundke-Iqbal, "Role of tau phosphorylation by glycogen synthase kinase- $3 \beta$ in the regulation of organelle transport," Journal of Cell Science, vol. 117, no. 9, pp. 1653-1663, 2004.

[65] I. Cuchillo-Ibanez, A. Seereeram, H. L. Byers et al., "Phosphorylation of tau regulates its axonal transport by controlling its binding to kinesin," FASEB Journal, vol. 22, no. 9, pp. 3186-3195, 2008.

[66] J. Dill, H. Wang, F. Zhou, and S. Li, "Inactivation of glycogen synthase kinase 3 promotes axonal growth and recovery in the CNS," Journal of Neuroscience, vol. 28, no. 36, pp. 89148928, 2008.

[67] S. B. Shim, H. J. Lim, K. R. Chae et al., "Tau overexpression in transgenic mice induces glycogen synthase kinase $3 \beta$ and $\beta$-catenin phosphorylation," Neuroscience, vol. 146, no. 2, pp. 730-740, 2007.

[68] J. H. Cho and G. V. W. Johnson, "Glycogen synthase kinase $3 \beta$ induces caspase-cleaved tau aggregation in situ," Journal of Biological Chemistry, vol. 279, no. 52, pp. 54716-54723, 2004.

[69] J. H. Peng, C. E. Zhang, W. Wei, X. P. Hong, XI. P. Pan, and J. Z. Wang, "Dehydroevodiamine attenuates tau hyperphosphorylation and spatial memory deficit induced by activation of glycogen synthase kinase-3 in rats," Neuropharmacology, vol. 52, no. 7, pp. 1521-1527, 2007.

[70] W. Chun and G. V. W. Johnson, "Activation of glycogen synthase kinase $3 \beta$ promotes the intermolecular association of tau: the use of fluorescence resonance energy transfer microscopy," Journal of Biological Chemistry, vol. 282, no. 32, pp. 23410-23417, 2007.

[71] T. Engel, J. J. Lucas, P. Gómez-Ramos, M. A. Moran, J. Ávila, and F. Hernández, "Cooexpression of FTDP-17 tau and GSK- $3 \beta$ in transgenic mice induce tau polymerization and neurodegeneration," Neurobiology of Aging, vol. 27, no. 9, pp. 1258-1268, 2006. 
[72] T. Engel, F. Hernández, J. Avila, and J. J. Lucas, "Full reversal of Alzheimer's disease-like phenotype in a mouse model with conditional overexpression of glycogen synthase kinase-3," Journal of Neuroscience, vol. 26, no. 19, pp. 5083-5090, 2006.

[73] M. Pérez, F. Hernández, F. Lim, J. Díaz-Nido, and J. Avila, "Chronic lithium treatment decreases mutant tau protein aggregation in a transgenic mouse model," Journal of Alzheimer's Disease, vol. 5, no. 4, pp. 301-308, 2003.

[74] H. Nakashima, T. Ishihara, P. Suguimoto et al., "Chronic lithium treatment decreases tau lesions by promoting ubiquitination in a mouse model of tauopathies," Acta Neuropathologica, vol. 110, no. 6, pp. 547-556, 2005.

[75] T. Engel, P. Goñi-Oliver, J. J. Lucas, J. Avila, and F. Hernández, "Chronic lithium administration to FTDP-17 tau and GSK$3 \beta$ overexpressing mice prevents tau hyperphosphorylation and neurofibrillary tangle formation, but pre-formed neurofibrillary tangles do not revert," Journal of Neurochemistry, vol. 99, no. 6, pp. 1445-1455, 2006.

[76] E. Gómez de Barreda, M. Pérez, P. Gómez Ramos et al., “Tauknockout mice show reduced GSK3-induced hippocampal degeneration and learning deficits," Neurobiology of Disease, vol. 37, no. 3, pp. 622-629, 2010.

[77] F. Hernández, M. Pérez, J. J. Lucas, A. M. Mata, R. Bhat, and J. Avila, "Glycogen synthase kinase-3 plays a crucial role in tau exon 10 splicing and intranuclear distribution of SC35: implications for Alzheimer's disease," Journal of Biological Chemistry, vol. 279, no. 5, pp. 3801-3806, 2004.

[78] L. Martin, A. Magnaudeix, F. Esclaire, C. Yardin, and F. Terro, "Inhibition of glycogen synthase kinase- $3 \beta$ downregulates total tau proteins in cultured neurons and its reversal by the blockade of protein phosphatase-2A," Brain Research, vol. 1252, no. C, pp. 66-75, 2009.

[79] A. Rametti, F. Esclaire, C. Yardin, N. Cogné, and F. Terro, "Lithium down-regulates tau in cultured cortical neurons: a possible mechanism of neuroprotection," Neuroscience Letters, vol. 434, no. 1, pp. 93-98, 2008.

[80] J. Götz, F. Chen, J. van Dorpe, and R. M. Nitsch, "Formation of neurofibrillary tangles in P301L tau transgenic mice induced by A 342 fibrils," Science, vol. 293, no. 5534, pp. 1491-1495, 2001.

[81] S. Melov, P. A. Adlard, K. Morten et al., "Mitochondrial oxidative stress causes hyperphosphorylation of tau," PLoS ONE, vol. 2, no. 6, article e536, 2007.

[82] A. Takashima, K. Noguchi, K. Sato, T. Hoshino, and K. Imahori, "Tau protein kinase I is essential for amyloid $\beta$ protein-induced neurotoxicity," Proceedings of the National Academy of Sciences of the United States of America, vol. 90, no. 16, pp. 7789-7793, 1993.

[83] A. Takashima, K. Noguchi, G. Michel et al., "Exposure of rat hippocampal neurons to amyloid $\beta$ peptide (25-35) induces the inactivation of phosphatidyl inositol-3 kinase and the activation of tau protein kinase I/glycogen synthase kinase$3 \beta$," Neuroscience Letters, vol. 203, no. 1, pp. 33-36, 1996.

[84] M. Hoshi, M. Sato, S. Matsumoto et al., "Spherical aggregates of $\beta$-amyloid (amylospheroid) show high neurotoxicity and activate tau protein kinase I/glycogen synthase kinase-3 $\beta$," Proceedings of the National Academy of Sciences of the United States of America, vol. 100, no. 11, pp. 6370-6375, 2003.

[85] Q.-L. Ma, G. P. Lim, M. E. Harris-White et al., "Antibodies against $\beta$-amyloid reduce $\mathrm{A} \beta$ oligomers, glycogen synthase kinase- $3 \beta$ activation and $\tau$ phosphorylation in vivo and in vitro," Journal of Neuroscience Research, vol. 83, no. 3, pp. 374-384, 2006.
[86] A. Takashima, T. Honda, K. Yasutake et al., "Activation of tau protein kinase I/glycogen synthase kinase- $3 \beta$ by amyloid $\beta$ peptide (25-35) enhances phosphorylation of tau in hippocampal neurons," Neuroscience Research, vol. 31, no. 4, pp. 317-323, 1998.

[87] A. E. Aplin, J. S. Jacobsen, B. H. Anderton, and J. M. Gallo, "Effect of increased glycogen synthase kinase-3 activity upon the maturation of the amyloid precursor protein in transfected cells," NeuroReport, vol. 8, no. 3, pp. 639-643, 1997.

[88] S. H. Koh, M. Y. Noh, and S. H. Kim, "Amyloid-beta-induced neurotoxicity is reduced by inhibition of glycogen synthase kinase-3," Brain Research, vol. 1188, no. 1, pp. 254-262, 2008.

[89] D. Terwel, D. Muyllaert, I. Dewachter et al., "Amyloid activates GSK-3 $\beta$ to aggravate neuronal tauopathy in bigenic mice," American Journal of Pathology, vol. 172, no. 3, pp. 786798, 2008.

[90] K. Ghosal, D. L. Vogt, M. Liang, Y. Shen, B. T. Lamb, and S. W. Pimplikar, "Alzheimer's disease-like pathological features in transgenic mice expressing the APP intracellular domain," Proceedings of the National Academy of Sciences of the United States of America, vol. 106, no. 43, pp. 18367-18372, 2009.

[91] G. Amadoro, V. Corsetti, M. T. Ciotti et al., "Endogenous A $\beta$ causes cell death via early tau hyperphosphorylation," Neurobiology of Aging. In press.

[92] E. D. Roberson, K. Scearce-Levie, J. J. Palop et al., "Reducing endogenous tau ameliorates amyloid $\beta$-induced deficits in an Alzheimer's disease mouse model," Science, vol. 316, no. 5825, pp. 750-754, 2007.

[93] L. M. Ittner, Y. D. Ke, F. Delerue et al., "Dendritic function of tau mediates amyloid- $\beta$ toxicity in alzheimer's disease mouse models," Cell, vol. 142, no. 3, pp. 387-397, 2010.

[94] A. E. Aplin, G. M. Gibb, J. S. Jacobsen, J. M. Gallo, and B. H. Anderton, "In vitro phosphorylation of the cytoplasmic domain of the amyloid precursor protein by glycogen synthase kinase-3 $\beta$," Journal of Neurochemistry, vol. 67, no. 2, pp. 699-707, 1996.

[95] C. Terracciano, A. Nogalska, W. K. Engel, and V. Askanas, "In APP-overexpressing cultured human muscle fibers proteasome inhibition enhances phosphorylation of APP751 and GSK3 activation: effects mitigated by lithium and apparently relevant to sporadic inclusion-body myositis," Journal of Neurochemistry, vol. 112, no. 2, pp. 389-396, 2010.

[96] F. Kirschenbaum, S. C. Hsu, B. Cordell, and J. V. McCarthy, "Glycogen synthase kinase- $3 \beta$ regulates presenilin $1 \mathrm{C}$ terminal fragment levels," Journal of Biological Chemistry, vol. 276, no. 33, pp. 30701-30707, 2001.

[97] F. Kirschenbaum, S. C. Hsu, B. Cordell, and J. V. McCarthy, "Substitution of a glycogen synthase kinase- $3 \beta$ phosphorylation site in presenilin 1 separates presenilin function from $\beta$-catenin signaling," Journal of Biological Chemistry, vol. 276, no. 10, pp. 7366-7375, 2001.

[98] C. Twomey and J. V. McCarthy, "Presenilin-1 is an unprimed glycogen synthase kinase- $3 \beta$ substrate," FEBS Letters, vol. 580, no. 17, pp. 4015-4020, 2006.

[99] C. J. Phiel, C. A. Wilson, V. M. Y. Lee, and P. S. Klein, "GSK$3 \alpha$ regulates production of Alzheimer's disease amyloid- $\beta$ peptides," Nature, vol. 423, no. 6938, pp. 435-439, 2003.

[100] J. Ryder, Y. Su, F. Liu, B. Li, Y. Zhou, and B. Ni, "Divergent roles of GSK3 and CDK5 in APP processing," Biochemical and Biophysical Research Communications, vol.312, no. 4, pp. 922-929, 2003. 
[101] E. Rockenstein, M. Torrance, A. Adame et al., "Neuroprotective effects of regulators of the glycogen synthase kinase- $3 \beta$ signaling pathway in a transgenic model of Alzheimer's disease are associated with reduced amyloid precursor protein phosphorylation," Journal of Neuroscience, vol. 27, no. 8, pp. 1981-1991, 2007.

[102] L. Serenó, M. Coma, M. Rodríguez et al., "A novel GSK$3 \beta$ inhibitor reduces Alzheimer's pathology and rescues neuronal loss in vivo," Neurobiology of Disease, vol. 35, no. 3, pp. 359-367, 2009.

[103] H. Decker, K. Y. Lo, S. M. Unger, S. T. Ferreira, and M. A. Silverman, "Amyloid- $\beta$ peptide oligomers disrupt axonal transport through an NMDA receptor-dependent mechanism that is mediated by glycogen synthase kinase $3 \beta$ in primary cultured hippocampal neurons," Journal of Neuroscience, vol. 30, no. 27, pp. 9166-9171, 2010.

[104] M. R. Cookson, "The biochemistry of Parkinson's disease," Annual Review of Biochemistry, vol. 74, pp. 29-52, 2005.

[105] P. Lei, S. Ayton, D. I. Finkelstein, P. A. Adlard, C. L. Masters, and A. I. Bush, "Tau protein: relevance to Parkinson's disease," International Journal of Biochemistry and Cell Biology, vol. 42, no. 11, pp. 1775-1778, 2010.

[106] J. Simón-Sánchez, C. Schulte, J. M. Bras et al., "Genome-wide association study reveals genetic risk underlying Parkinson's disease," Nature Genetics, vol. 41, no. 12, pp. 1308-1312, 2009.

[107] T. L. Edwards, W. K. Scott, C. Almonte et al., "Genome-Wide association study confirms SNPs in SNCA and the MAPT region as common risk factors for parkinson disease," Annals of Human Genetics, vol. 74, no. 2, pp. 97-109, 2010.

[108] M. Nagao and H. Hayashi, "Glycogen synthase kinase-3beta is associated with Parkinson's disease," Neuroscience Letters, vol. 449, no. 2, pp. 103-107, 2009.

[109] J. Wills, J. Jones, T. Haggerty, V. Duka, J. N. Joyce, and A. Sidhu, "Elevated tauopathy and alpha-synuclein pathology in postmortem Parkinson's disease brains with and without dementia," Experimental Neurology, vol. 225, no. 1, pp. 210$218,2010$.

[110] T. Duka, V. Duka, J. N. Joyce, and A. Sidhu, " $\alpha$-synuclein contributes to GSK-3 $\beta$-catalyzed Tau phosphorylation in Parkinson's disease models," FASEB Journal, vol. 23, no. 9, pp. 2820-2830, 2009.

[111] M. T. Armentero, E. Sinforiani, C. Ghezzi et al., "Peripheral expression of key regulatory kinases in Alzheimer's disease and Parkinson's disease," Neurobiology of Aging. In press.

[112] J. B. J. Kwok, M. Hallupp, C. T. Loy et al., "GSK3B polymorphisms alter transcription and splicing in Parkinson's disease," Annals of Neurology, vol. 58, no. 6, pp. 829-839, 2005.

[113] I. García-Gorostiaga, P. Sánchez-Juan, I. Mateo et al., "Glycogen synthase kinase- $3 \beta$ and tau genes interact in Parkinson's and Alzheimer's diseases," Annals of Neurology, vol. 65, no. 6, pp. 759-761, 2009.

[114] P. J. Khandelwal, S. B. Dumanis, L. R. Feng et al., "Parkinsonrelated parkin reduces $\alpha$-synuclein phosphorylation in a gene transfer model," Molecular Neurodegeneration, vol. 5, no. 1, p. 47, 2010.

[115] W. Wang, Y. Yang, C. Ying et al., "Inhibition of glycogen synthase kinase- $3 \beta$ protects dopaminergic neurons from MPTP toxicity," Neuropharmacology, vol. 52, no. 8, pp. 1678 1684, 2007.

[116] C. J. Phiel and P. S. Klein, "Molecular targets of lithium action," Annual Review of Pharmacology and Toxicology, vol. 41, pp. 789-813, 2001.
[117] J. F. Cade, "Lithium salts in the treatment of psychotic excitement," The Medical Journal of Australia, vol. 2, no. 10, pp. 349-352, 1949.

[118] K. N. Fountoulakis, E. Vieta, C. Bouras et al., "A systematic review of existing data on long-term lithium therapy: neuroprotective or neurotoxic?" International Journal of Neuropsychopharmacology, vol. 11, no. 2, pp. 269-287, 2008.

[119] W. T. O’Brien, A. D. Harper, F. Jové et al., “Glycogen synthase kinase- $3 \beta$ haploinsufficiency mimics the behavioral and molecular effects of lithium," Journal of Neuroscience, vol. 24, no. 30, pp. 6791-6798, 2004.

[120] J. Prickaerts, D. Moechars, K. Cryns et al., "Transgenic mice overexpressing glycogen synthase kinase $3 \beta$ : a putative model of hyperactivity and mania," Journal of Neuroscience, vol. 26, no. 35, pp. 9022-9029, 2006.

[121] P. S. Klein and D. A. Melton, "A molecular mechanism for the effect of lithium on development," Proceedings of the National Academy of Sciences of the United States of America, vol. 93, no. 16, pp. 8455-8459, 1996.

[122] W. J. Ryves and A. J. Harwood, "Lithium inhibits glycogen synthase kinase- 3 by competition for magnesium," Biochemical and Biophysical Research Communications, vol. 280, no. 3, pp. 720-725, 2001.

[123] E. Chalecka-Franaszek and DE. M. Chuang, "Lithium activates the serine/threonine kinase Akt-1 and suppresses glutamate-induced inhibition of Akt-1 activity in neurons," Proceedings of the National Academy of Sciences of the United States of America, vol. 96, no. 15, pp. 8745-8750, 1999.

[124] P. De Sarno, X. Li, and R. S. Jope, "Regulation of Akt and glycogen synthase kinase- $3 \beta$ phosphorylation by sodium valproate and lithium," Neuropharmacology, vol. 43, no. 7, pp. 1158-1164, 2002.

[125] C. M. Hedgepeth, L. J. Conrad, J. Zhang, H. C. Huang, V. M. Y. Lee, and P. S. Klein, "Activation of the Wnt signaling pathway: a molecular mechanism for lithium action,” Developmental Biology, vol. 185, no. 1, pp. 82-91, 1997.

[126] A. Caccamo, S. Oddo, L. X. Tran, and F. M. LaFerla, "Lithium reduces tau phosphorylation but not $\mathrm{A} \beta$ or working memory deficits in a transgenic model with both plaques and tangles," American Journal of Pathology, vol. 170, no. 5, pp. 1669-1675, 2007.

[127] M. Hong, D. C. R. Chen, P. S. Klein, and V. M. Y. Lee, "Lithium reduces tau phosphorylation by inhibition of glycogen synthase kinase-3," Journal of Biological Chemistry, vol. 272, no. 40, pp. 25326-25332, 1997.

[128] J. R. Muñoz-Montaño, F. J. Moreno, J. Avila, and J. DíazNido, "Lithium inhibits Alzheimer's disease-like tau protein phosphorylation in neurons," FEBS Letters, vol. 411, no. 2-3, pp. 183-188, 1997.

[129] S. Lovestone, D. R. Davis, M. T. Webster et al., "Lithium reduces tau phosphorylation: effects in living cells and in neurons at therapeutic concentrations," Biological Psychiatry, vol. 45, no. 8, pp. 995-1003, 1999.

[130] X. Sun, S. Sato, O. Murayama et al., "Lithium inhibits amyloid secretion in COS7 cells transfected with amyloid precursor protein C100," Neuroscience Letters, vol. 321, no. 1-2, pp. 61-64, 2002.

[131] Y. Su, J. Ryder, B. Li et al., "Lithium, a common drug for bipolar disorder treatment, regulates amyloid- $\beta$ precursor protein processing," Biochemistry, vol. 43, no. 22, pp. 68996908, 2004 
[132] C. Feyt, P. Kienlen-Campard, K. Leroy et al., "Lithium chloride increases the production of amyloid- $\beta$ peptide independently from its inhibition of glycogen synthase kinase 3," Journal of Biological Chemistry, vol. 280, no. 39, pp. 33220-33227, 2005.

[133] M. L. Selenica, H. S. Jensen, A. K. Larsen et al., "Efficacy of small-molecule glycogen synthase kinase-3 inhibitors in the postnatal rat model of tau hyperphosphorylation," British Journal of Pharmacology, vol. 152, no. 6, pp. 959-979, 2007.

[134] E. Tsaltas, D. Kontis, V. Boulougouris et al., "Enhancing effects of chronic lithium on memory in the rat," Behavioural Brain Research, vol. 177, no. 1, pp. 51-60, 2007.

[135] E. Tsaltas, T. Kyriazi, C. Poulopoulou, D. Kontis, and A. Maillis, "Enhancing effects of lithium on memory are not by-products of learning or attentional deficits," Behavioural Brain Research, vol. 180, no. 2, pp. 241-245, 2007.

[136] O. Sofola, F. Kerr, I. Rogers et al., "Inhibition of GSK3 ameliorates $\mathrm{A} \beta$ pathology in an adult-onset Drosophila model of Alzheimer's disease," PLoS Genetics, vol. 6, no. 9, Article ID e1001087, 2010.

[137] E. M. Toledo and N. C. Inestrosa, "Activation of Wnt signaling by lithium and rosiglitazone reduced spatial memory impairment and neurodegeneration in brains of an APPswe/PSEN1 $\triangle \mathrm{E} 9$ mouse model of Alzheimer's disease," Molecular Psychiatry, vol. 15, no. 3, pp. 272-285, 2010.

[138] A. Fiorentini, M. C. Rosi, C. Grossi, I. Luccarini, and F. Casamenti, "Lithium improves hippocampal neurogenesis, neuropathology and cognitive functions in APP mice," PLoS ONE, vol. 5, no. 12, Article ID e14382, 2010.

[139] K. Leroy, K. Ando, C. Héraud et al., "Lithium treatment arrests the development of neurofibrillary tangles in mutant tau transgenic mice with advanced neurofibrillary pathology," Journal of Alzheimer's Disease, vol. 19, no. 2, pp. 705719, 2010.

[140] W. W. Havens and J. Cole, "Successful treatment of dementia with lithium," Journal of Clinical Psychopharmacology, vol. 2, no. 1, pp. 71-72, 1982.

[141] E. Tsaltas, D. Kontis, V. Boulougouris, and G. N. Papadimitriou, "Lithium and cognitive enhancement: leave it or take it?" Psychopharmacology, vol. 202, no. 1-3, pp. 457-476, 2009.

[142] P. V. Nunes, O. V. Forlenza, and W. F. Gattaz, "Lithium and risk for Alzheimer's disease in elderly patients with bipolar disorder," British Journal of Psychiatry, vol. 190, pp. 359-360, 2007.

[143] T. Terao, H. Nakano, Y. Inoue, T. Okamoto, J. Nakamura, and N. Iwata, "Lithium and dementia: a preliminary study," Progress in Neuro-Psychopharmacology and Biological Psychiatry, vol. 30, no. 6, pp. 1125-1128, 2006.

[144] L. V. Kessing, J. L. Forman, and P. K. Andersen, "Does lithium protect against dementia?" Bipolar Disorders, vol. 12, no. 1, pp. 87-94, 2010.

[145] A. Macdonald, K. Briggs, M. Poppe, A. Higgins, L. Velayudhan, and S. Lovestone, "A feasibility and tolerability study of lithium in Alzheimer's disease," International Journal of Geriatric Psychiatry, vol. 23, no. 7, pp. 704-711, 2008.

[146] N. Dunn, C. Holmes, and M. Mullee, "Does lithium therapy protect against the onset of dementia?" Alzheimer Disease and Associated Disorders, vol. 19, no. 1, pp. 20-22, 2005.

[147] H. Hampel, M. Ewers, K. Bürger et al., "Lithium trial in Alzheimer's disease: a randomized, single-blind, placebocontrolled, multicenter 10-week study," Journal of Clinical Psychiatry, vol. 70, no. 6, pp. 922-931, 2009.
[148] T. Leyhe, G. W. Eschweiler, E. Stransky et al., "Increase of bdnf serum concentration in lithium treated patients with early Alzheimer's disease," Journal of Alzheimer's Disease, vol. 16, no. 3, pp. 649-656, 2009.

[149] M. B. H. Youdim and Z. Arraf, "Prevention of MPTP (Nmethyl-4-phenyl-1,2,3,6-tetrahydropyridine) dopaminergic neurotoxicity in mice by chronic lithium: involvements of Bcl-2 and Bax," Neuropharmacology, vol. 46, no. 8, pp. 11301140, 2004.

[150] E. Friedman and S. Gershon, "Effect of lithium on brain dopamine," Nature, vol. 243, no. 5409, pp. 520-521, 1973.

[151] M. Dziedzicka-Wasylewska, M. Maćkowiak, K. Fijat, and K. Wędzony, "Adaptive changes in the rat dopaminergic transmission following repeated lithium administration," Journal of Neural Transmission, vol. 103, no. 7, pp. 765-776, 1996.

[152] Y. Yong, H. Ding, Z. Fan, J. Luo, and Z.-J. Ke, "Lithium fails to protect dopaminergic neurons in the 6-ohda model of parkinson's disease," Neurochemical Research, vol. 36, no. 3, pp. 367-374, 2010.

[153] H. L. Feng, Y. Leng, C. H. Ma, J. Zhang, M. Ren, and D. M. Chuang, "Combined lithium and valproate treatment delays disease onset, reduces neurological deficits and prolongs survival in an amyotrophic lateral sclerosis mouse model," Neuroscience, vol. 155, no. 3, pp. 567-572, 2008.

[154] F. Fornai, P. Longone, L. Cafaro et al., "Lithium delays progression of amyotrophic lateral sclerosis," Proceedings of the National Academy of Sciences of the United States of America, vol. 105, no. 6, pp. 2052-2057, 2008.

[155] A. Gill, J. Kidd, F. Vieira, K. Thompson, and S. Perrin, "No benefit from chronic lithium dosing in a sibling-matched, gender balanced, investigator-blinded trial using a standard mouse model of familial ALS," PLOS ONE, vol. 4, no. 8, Article ID e6489, 2009.

[156] S. P. Aggarwal, L. Zinman, E. Simpson et al., "Safety and efficacy of lithium in combination with riluzole for treatment of amyotrophic lateral sclerosis: a randomised, double-blind, placebo-controlled trial," The Lancet Neurology, vol. 9, no. 5, pp. 481-488, 2010. 


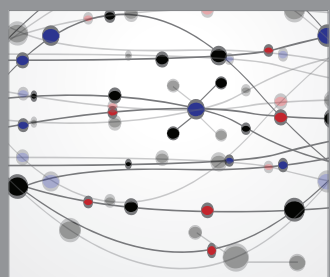

The Scientific World Journal
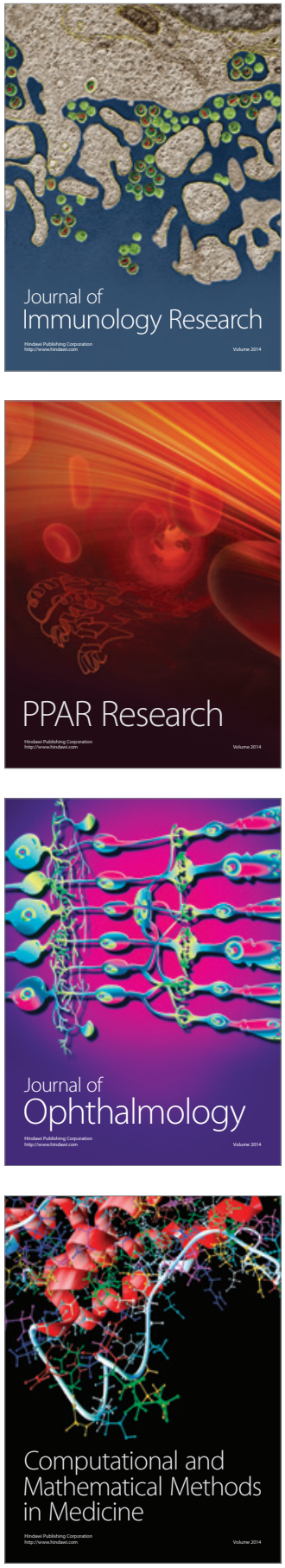

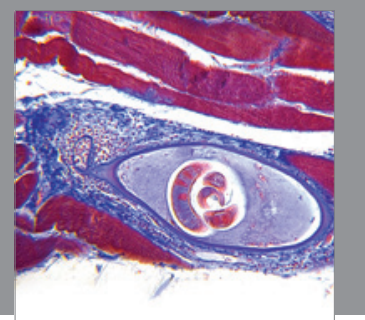

Gastroenterology

Research and Practice
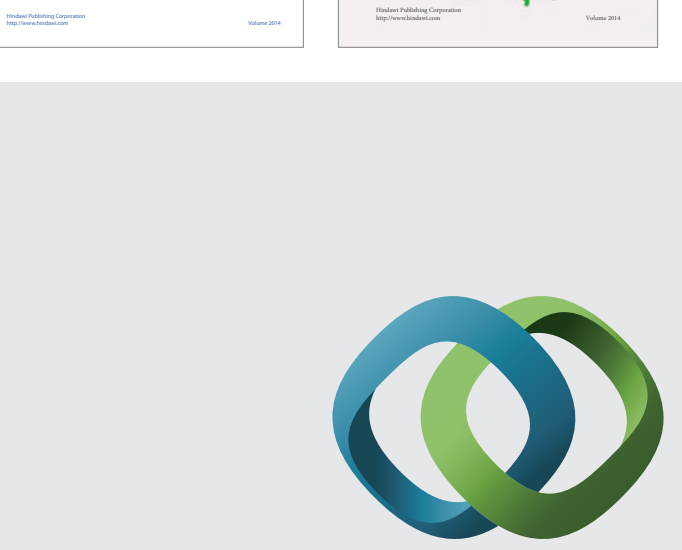

\section{Hindawi}

Submit your manuscripts at

http://www.hindawi.com
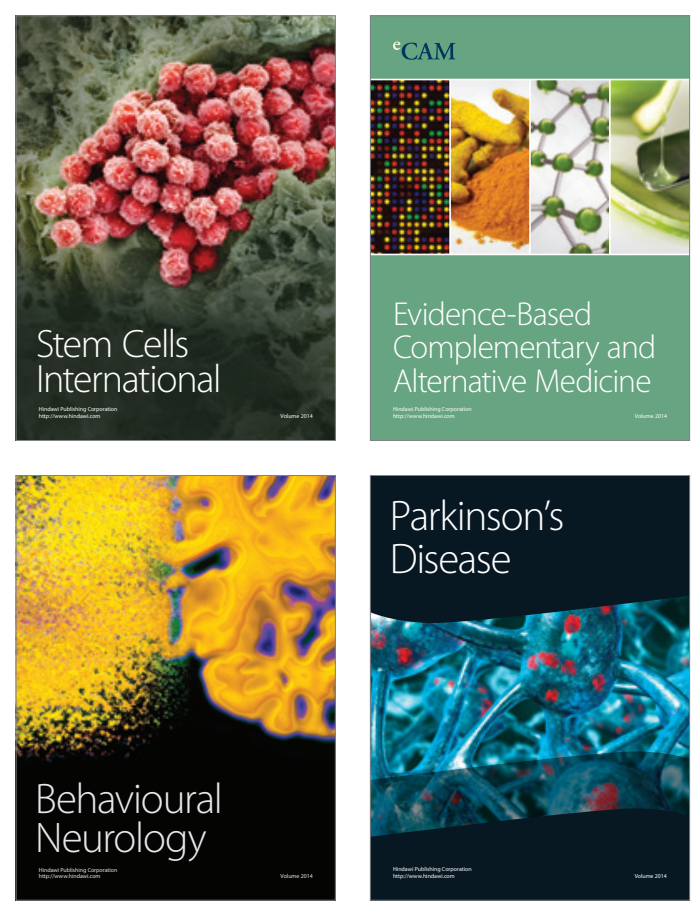

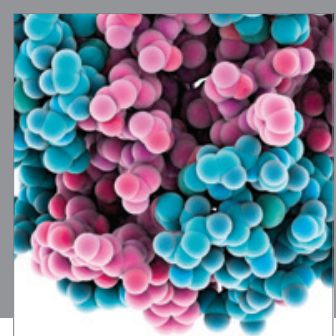

Journal of
Diabetes Research

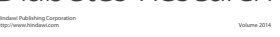

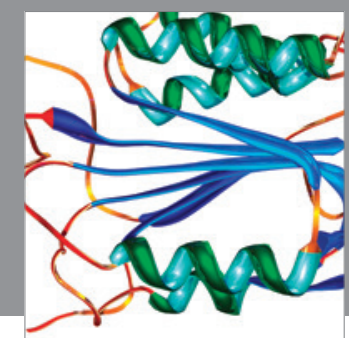

Disease Markers
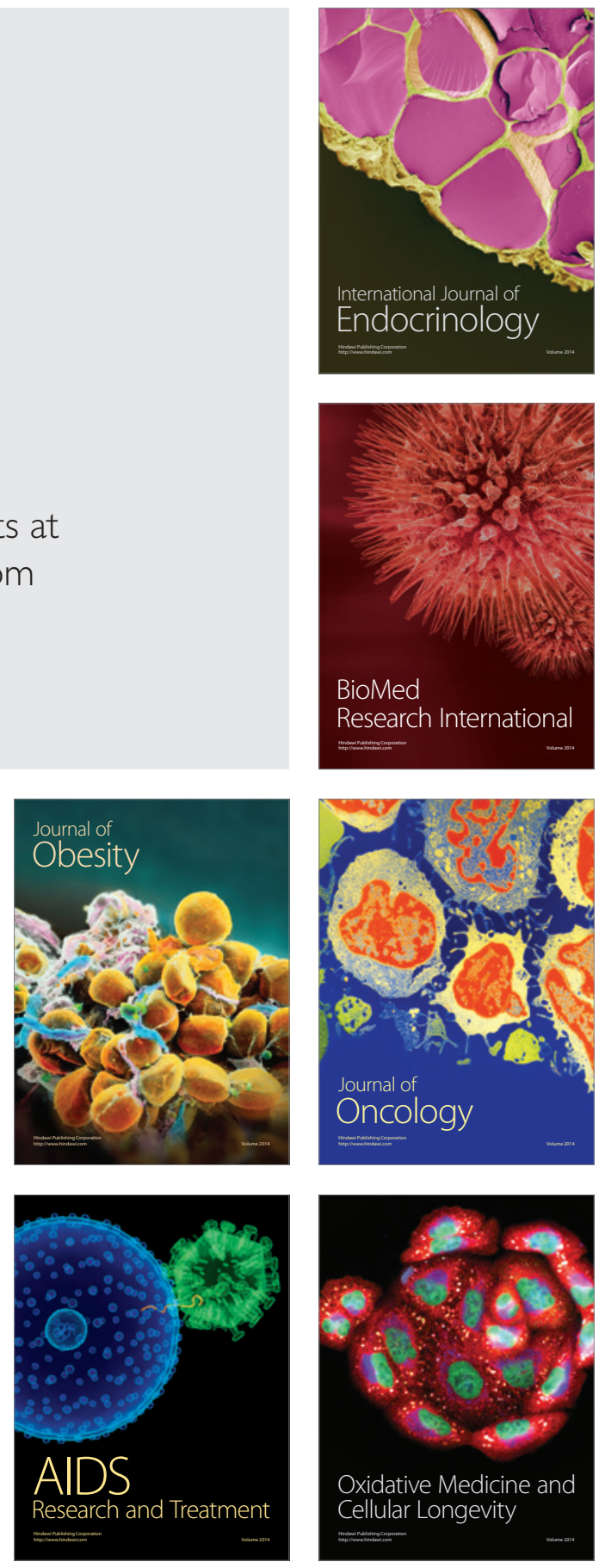